\title{
The unconquerable country: the Babylonian marshes in the Neo-Assyrian sources
}

\author{
Ariel M. Bagg ${ }^{1}$ \\ Received: 24 June 2019 / Accepted: 2 April 2020 / Published online: 20 April 2020 \\ (c) The Author(s) 2020
}

\begin{abstract}
The Assyrians ruled in the first half of the first millennium BCE over most part of the Ancient Near East. The Neo-Assyrian Empire was constructed on the base of a powerful, well organized and trained army, which defeated all enemies and seemed to be invincible. Babylonia was a special case, because of the complicated political situation and especially its particular geography. Southern Babylonia (nowadays Southern Iraq) was a region of marshes and lagoons, an ideal refuge for rebels. The area could become a mortal trap for those who entered it without knowing it well enough. This region, which represented a severe challenge for the Assyrian army, was called in the Assyrian sources the "Sealand", a region where water played a crucial role. The aim of this paper is to show how this particular landscape was perceived by the Assyrians as well as to point out its decisive role in the development of the historical events on the base of the cuneiform sources and the depictions on the stone plates, which decorated the walls of the Assyrian palaces.
\end{abstract}

Keywords Assyria $\cdot$ Babylonia $\cdot$ Marshland $\cdot$ Navigation $\cdot$ Southern iraq

\section{Introduction}

After regaining the boundaries of the Middle Assyrian period during the ninth century BCE, the Assyrian empire grew inexorably during the following two centuries. The Assyrian kings campaigned almost yearly, conquering all the regions and kingdoms within or at the natural borders of the empire. ${ }^{1}$ The efficient and fearsome Assyrian army functioned like a well-oiled machine, even in difficult terrain like mountain areas or deserts. The defeated enemies could retain a certain independency as vassals or be annexed to the empire as a province under an Assyrian governor. Babylonia, the southern neighbour of Assyria, represented a special case. After Tiglath-pileser III's conquest, different rule

\footnotetext{
1 Bagg (2019).
}

Ariel M. Bagg

ariel.bagg@ori.uni-heidelberg.de

1 Heidelberg University, Heidelberg, Germany 
systems were applied there ${ }^{2}$ and it was necessary to reconquer the region many times. Babylonia was indeed a problem for various reasons. Without doubt, the weight of its cultural heritage and the respect for it played an important role, ${ }^{3}$ but two other factors were as or even more important: the political situation and the geography. ${ }^{4}$ Babylonia was not a monolithic state but consisted on the one hand of the traditional Babylonian cities, and on the other hand of several Aramaean ${ }^{5}$ and Chaldean tribes. ${ }^{6}$ Furthermore, external actors like Elam or Arabian tribes intervened when alliances were built for or against Assyria. ${ }^{7}$ Moreover, Southern Babylonia was mostly a region of marshes and lagoons, an ideal refuge for rebels. The extensive marshes could become a mortal trap for those who entered the area without knowing it well enough. This region, which represented a severe challenge for the Assyrian army, was called Māt-tâmti, the "Sealand" (Fig. 1). The aim of this paper is to show how this particular landscape was perceived by the Assyrians as well as to point out its decisive role in the development of the historical events.

\section{The Sealand}

The term Māt-tâmti is first attested in the Kassite period ${ }^{8}$ and, according to the Babylonian king-lists, three dynasties ruled there-two in the second and one in the first millennium. ${ }^{9}$ The Sealand is best documented in the first half of the first millennium in Assyrian ${ }^{10}$ as well as in Babylonian sources, ${ }^{11}$ at the time when the interests of this region and those of the Assyrian Empire crossed. In fact, most of the attestations of Māt-tâmti come from Ashurbanipal's Babylonian correspondence. During this period, the Sealand was closely related to the Chaldean tribe Bît-Jakinn, whose leaders often ruled over the Sealand as governors. ${ }^{12}$ Marduk-apla-iddina, the archenemy

\footnotetext{
${ }^{2}$ Direct rule by the Assyrian king (Tiglath-pileser III, Shalmaneser V, Sargon II and Sennacherib were also kings of Babylonia), indirect rule by an Assyrian prince (Aššur-nādin-šumi, Sennacherib's son, and Šamaššumu-ukīn, Ashurbanipal's brother) or by a native loyal to Assyria (Bēl-ibni appointed as king of Babylonia by Sennacherib [PNA 1/II, 305-306, s. v. Bēl-ibni 9] and the homonymous official who was military commander of the Sealand during the reign of Ashurbanipal [PNA 1/II, 306-310, s. v. Bēl-ibni 18]).

3 Machinist (1984-1985).

4 Brinkman (1973).

5 For the Aramaeans in Babylonia see Streck (2014).

6 The Chaldean tribes in Babylonia were Bīt-Amukkāni, Bīt-Dakkūri, Bīt-Jakīn, Bīt-ŠSa'alli, and Bīt-Šilāni. For the non-native population in Babylonia s. also Fales (2011).

7 For the complicated Babylonian history during the late Neo-Assyrian period see Frame (1992).

8 RGTC 5, pp. 193-194.

9 For an historical overview of the Sealand see Brinkman (1993-1997).

10 tam-tim (RINAP 1, Tigl No. 47, Vs. 26); KUR-tam-ti (RIMA 3, 102.59, 47; SAA 10, 169,1); KUR-tamtim (RINAP 1, Tigl No. 51, 19; RINAP 3/1, No. 34, 8; RINAP 4, No. 1, ii, 40. 62; id. No. 2, ii, 32 ; id. No. 6, ii', 6'; id. 30, 6'; id. No. 31, 7'; Asb A, iii, 98 and iv, 97; BIWA 315, 68, rev. 31; SAA 11, 1, rev. i, 4'); KUR-ti-amat (SAA 4, 302, 4); KUR-A.AB.BA (ADD 888, 6, 8); KUR-tam-tim-a-a (SAA 4, 280, Rs. 1).

11 RGTC 8, 226-227 with the following additions: KUR-tam-tim (CT 54, 115, Rs. 2; CT 54, 185 [Arnold 1985, 148-149, rev. 1], rev. 1; CT 54, 201, 6. 14. rev. 10 [AOAT 242, 339-340]; CT 54, 233, 5'; CT 54, 511, rev. 17; SAA 17, 145, 13 [ABL 1029+]; SAA 18, 2, rev. 3 [ABL 1256]); lúKUR-tam-tim (CT 54, 52, rev. 2').

12 Such is the case of Nabû-zēr-kitti-līšir (PNA 2/II, 906, s.v. No. 3), Na'id-Marduk (PNA 2/II, 918, s. v. No. 2) —both sons of Marduk-apla-iddina - and Nabû-bēl-šumāti (PNA 2/II, 811-814, s.v. No. 10), Marduk-apla-iddina's grandson. For the identification of Bīt-Jakīn with the Sealand see Frame (1992, pp. 41-42).
} 
of the Sargonides, ${ }^{13}$ is even referred to in Tiglath-pileser's inscriptions as king of the Sealand. ${ }^{14}$

We know that the Sealand was located in the southernmost part of Babylonia, roughly in the marshy region east of Ur, but the information about its extent is scarce. It is clear from the sources that the Sealand extended to the Arabian Gulf. In the inscription on Shalmaneser's throne base concerning his Babylonian campaign on behalf of Marduk-zākir-šumi, when his brother rebelled against him, we read: "I received tribute from the kings of Chaldea as far as the sea (and) imposed my powerful might upon the Sealand". ${ }^{15}$ Furthermore, Ashurbanipal mentions that his brother Šamaš-šumu-ukīn instigated Babylonians, Chaldeans, Aramaeans and people of the Sealand to rebel against Assyria and gives as borders for the alluded region "from Aqaba to Bāb-salimeti". ${ }^{16}$ According to Sennacherib's report on his 6th campaign, Bāb-salimēti was a seaport at the head of the Arabian Gulf. ${ }^{17}$

However, the exact location of the head of the Arabian Gulf at that time is still unknown, and the seashore line cannot be ascertained. After a steady rising for about ten thousand years, the sea-level stabilized around 3500 BCE. It was argued in the past that it was 1-2 m above present levels, and that the sea penetrated about $200 \mathrm{~km}^{\text {inland }}{ }^{18}$ (see conjectural coastline in Fig. 1). However, geomorphological studies showed no evidence for such a high sea-level and a consequent large marine gulf that would have extended up to modern Nasiriyah, ${ }^{19}$ confirming the evidence from Sumerian sources, which was not compatible with that shoreline. ${ }^{20}$ Once the sea-level rise decelerated, alluvial sedimentation gradually pushed the coastline to the south to its present position. As the lower Mesopotamian plains are almost flat, the Tigris and the Euphrates tended on the one hand to adopt new river beds (avulsion), and on the other hand to branch into a network of channels (anastomosis). ${ }^{21}$ In the marsh region the twin rivers get almost lost in shallow reed swamps. ${ }^{22}$ Furthermore, in the estuarine zone the tidal effect of the Arabian Gulf is important. The Sealand must therefore have been a mosaic of brackish and fresh marshes, lagoons and intertidal flats.

The marshes in Southern Mesopotamia played an important role in the development of early states $^{23}$ and were up to the end of the twentieth century the largest wetlands in the Middle East and even in Western Eurasia. They covered in the 1970s a surface of about 15,000 to $20,000 \mathrm{~km} .^{24}$ This wetland environment was characterized since historical times

\footnotetext{
13 For Marduk-apla-iddina's long resistance against the Assyrian power and the correspondent attestations in the cuneiform sources see Brinkman (1964), Brinkman and Seidl (1987-1990, p. 375), and PNA 2/II, 705-710 (H. D. Baker).

14 RINAP 4, Tigl No. 47, obv. 26 and No. 51, 19.

15 RIMA 3, 102.59, 47.

16 BIWA 40, A, iii, 98-99. It is not quite clear if Aqaba was the northern border of the whole region or of the Sealand. If the identification (based only on the similarity of the names) of Aqaba with the homonymous city on the Euphrates, about 16 km downstream from Hit (Parpola and Porter 2001, 10 B3) is correct, it lay too far northwest to be considered the northern border of the Sealand.

17 RINAP 3/2, No. 46, 70 and 100.

18 Aqrawi (2001), Morgan (1900), Sanlaville (1989).

19 Gasche (2004, 2005, especially pp. 5-6; Gasche 2007, Heyvaert and Baeteman (2007); for a short but informative summary see Wilkinson (2012, pp. 19-21).

${ }^{20}$ For a discussion of the sources see Waetzold (1981). However see the-not quite convincing-objections by Heimpel (1987, p. 34 note 41).

21 Wilkinson (2013, pp. 35-40).

22 For the description of the landscape see Hritz (2005, pp. 21-31).

23 Hritz et al. (2012) and Pournelle and Algaze (2004).

24 Source UNEP (2001), quoted by Al-Mudaffar Fawzi et al. (2016, p. 1).
} 


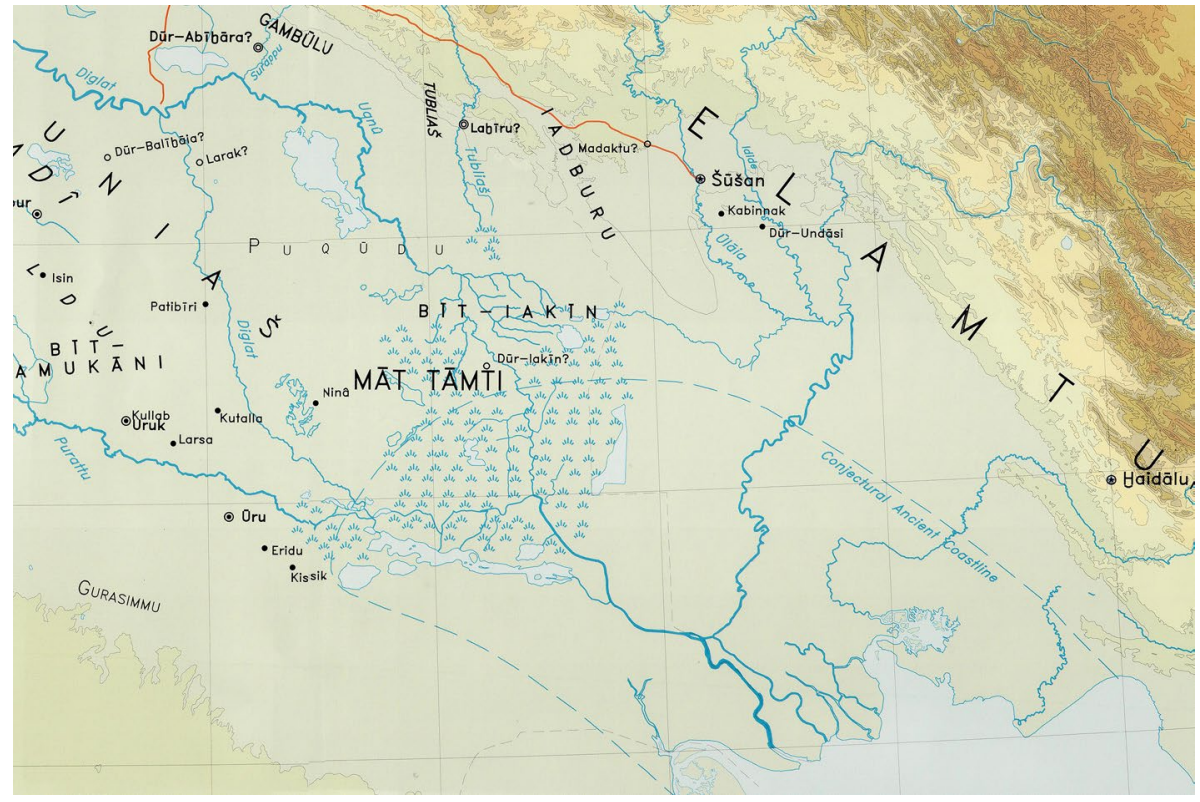

Fig. 1 The Sealand (Māt-tâmti) and the Babylonian marshes. Source Parpola and Porter (2001), wall-map, detail (with kind permission from the authors)

by a rich biodiversity, providing a great variety of resources to people living there and a habitat for plants, fish, birds, and wildlife. ${ }^{25}$ This ecosystem was severely destroyed in the 1980s during the Iraq-Iran war, but it was in the 1990s when it almost disappeared as a result of systematic desiccation. During the regime of Saddam Hussein the government drained over $90 \%$ of the marshes principally with the military goal of crushing people who lived or took refuge there. ${ }^{26}$ The population shrunk from about 500,000 in the 1950 s to 20,000 in $2003 .{ }^{27}$ The desiccation of the marshes changed drastically how Marsh Arabs, and especially women, interacted with their environment with the consequent loss of ancient marsh-specific knowledge and skills. ${ }^{28}$ Their huts and boats for instance show amazing similitudes with those attested in the iconography of ancient Mesopotamia. Nowadays, the Mesopotamian marshland is located mainly in southern Iraq and partially in southwestern Iran and Kuwait. ${ }^{29}$ It comprises three separate, but adjacent marshes: the Hawizeh, the Central and the Hammar Marshes (Fig. 2). Iraq joined the Ramsar Convention on Wetlands ${ }^{30}$ in 2007 and since then the Hawizeh Marsh is a protected site. The two other marshes became protected sites in $2014 .^{31}$

\footnotetext{
25 Pournelle and Algaze (2004, pp. 7-12).

26 Al-Mudaffar Fawzi et al. (2016, pp. 1-2) and Jema (2015, pp. 8-14).

27 Source Nicholson and Clark (2002), quoted by Al-Mudaffar Fawzi et al. (2016, p. 1).

28 Al-Mudaffar Fawzi et al. (2016).

29 For the restoration of the marshes after 2003 see Jema (2015).

30 The Ramsar Convention on Wetlands is an international treaty for the conservation and wise use of wetlands signed in the Iranian city of Ramsar in 1971 (www.ramsar.com).

31 Sauter (2016). Regaining the marshes has not been straightforward, especially since the many interven-
} 


\section{The Sealand in the sources}

The ancient sources give some clues as to who lived in the Mesopotamian marshland and what the landscape looked like in the first millennium. Two terms are used in the written sources to refer to the marshland in southern Babylonia: agammu "marsh, swamp"32 and appāru "reed marsh, canebrake". ${ }^{33}$ The Sealand was inhabited by Chaldeans and Aramaeans. Šūzubu (Mušēzib-Marduk), the Chaldean leader of Bīt-Dakkūri, is referred to in Sennacherib's inscriptions as "a Chaldean who lives among the marshes (agammu)"34 and Bīt-Jakīn is described as the land "which is in the marshes (agammu) and canebrakes (appāru)" ${ }^{35}$ Concerning Bēl-iqī̌sa, the leader of the mighty Aramaean tribe of Gambūlu, Esarhaddon says that his residence "is located twelve leagues distance in water and canebrakes (appāru) like (that of) a fish" ${ }^{36}$ In a letter addressed to Esarhaddon, Nabû-ušallim, then ruler of Bīt-Dakkūri, ${ }^{37}$ mentions trouble with people living in the marshes (appāru), who are called lúbașīhu or lúmașīhu "marsh dwellers". ${ }^{38}$ They were settled in the past in Bīt-Amukāni, the territory of another Chaldean tribe, and they should be resettled, otherwise they will not do the work of the king. ${ }^{39}$

Concerning the geographical distribution of the marshes, there is only little information in the sources. We learn from the report of Sennacherib's first campaign (late 704-early 702) about the marshes of Guzumānnu, a region in Bīt-Dakkūri. Pursuing Marduk-aplaiddina, who fled there, Sennacherib ordered his warriors "into the midst of marshes and canebrakes". ${ }^{40}$ Another marsh existed near the city of Sahrīna according to an epigraph and the corresponding reliefs from room LXX of Sennacherib's Southwest Palace ${ }^{41}$ : "Sennacherib, king of the world, king of Assyria. The booty of the marshes (agammu) of the city Sahrīna passed before him". ${ }^{42}$ Sahrīna, if identical with Šahrinu in the Babylonian sources, ${ }^{43}$ was a city on the Nār-Barsip, between Babylon and Borsippa. ${ }^{44}$ The same city is probably also identical with Șahrīna, one of the fortresses in Bīt-Dakkūri conquered by

Footnote 31 (continued)

tions on the Tigris and Euphrates, with dams on many upstream locations, also led to marsh desiccation. It is likely that climate change, with the last decades being dryer, is also likely to have an effect.

32 CAD A/1, 142, especially meaning b.

33 CAD A/1, 179-181, especially meaning b on p. 181. A further, less attested term is șuṣ̂ "canebrake, reed thicket, swamp", CAD Ș, 262. Sennacherib used this term for his artificial swamp (s. below): RINAP 3/1, No. 8, 5'; id., 16, viii, 31; id., 17, viii, 47; 18, viii, 8"; RINAP 3/2, No. 46, 157; id., No. 138, rev. ii', 36.

34 RINAP 3/1, No. 22, iii, 52-54; RINAP 3/2, No. 46, 33.

35 RINAP 3/1, No. 22, iii, 68 and RINAP 3/2, No. 46, 36.

36 RINAP 4, No. 2, iii, 37-39; RINAP 4, No. 1, iii, 71-73 and No. 7, 11'-12' omit "like (that of) a fish"; RINAP 4, No. 30, 13' and No. 31, 9' offer the variant "whose residence is located twelve leagues distance in swamps (agammu) and canebrakes (apparu)".

37 PNA 2/II, 903-904, s. v. Nabû-ušallim 11.

38 SAA 18, 185, 5-6. The term is otherwise not attested, s. AHw 1547, s. v. According to Zadok (2013, p. 280) the term may be related to the Aramaean root *ms " "to lie in the middle".

39 SAA $18,185$.

40 RINAP 3/1, 111.1, 25-26 and 34.

41 Barnett (1998b, plate 462, Nos 643 (slab 1), 645 (slab 3) and 646 (slab 4), and plate 466, No. 646a (slab 4)).

42 RINAP 3/2, 111.61 .

43 Cole (1994, p. 90 with note 46).

44 RGTC 8, pp. 283-284; see also Unger (1931, pp. 89-90). 


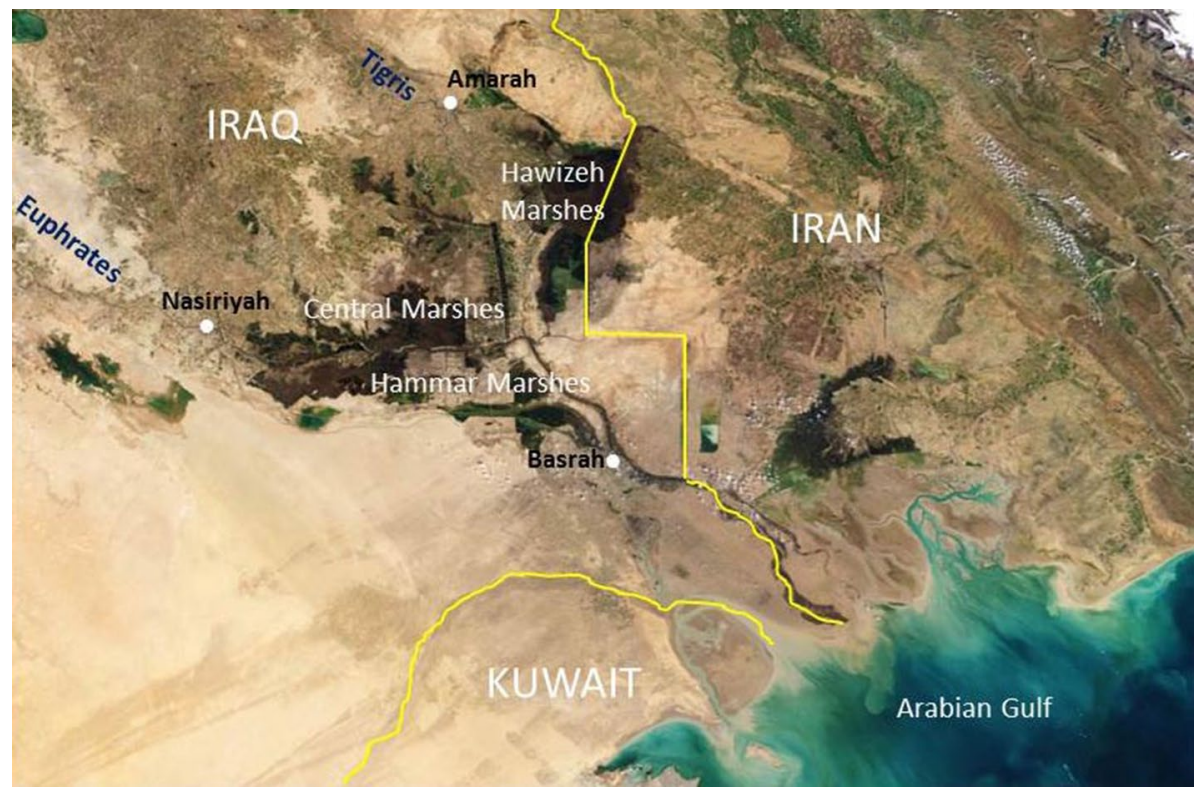

Fig. 2 Marshes in southern Iraq (2007). Source NASA Earth Observatory (photo; contents by the author)

Sennacherib during his first campaign. ${ }^{45}$ According to sources from the Neo-Babylonian period there existed also a marsh near Borsippa (Birs Nimrud). ${ }^{46}$ The body of water was so impressive that in the sixth century the morass around Borsippa began to be called tâmtu, the "Sea". ${ }^{47}$ Layard, who visited Birs Nimrud in late 1849, stressed the extension of the marsh around the site. ${ }^{48}$ In a letter addressed to Sargon $^{49}$ a Qatannu marsh is mentioned, probably located near Uruk, ${ }^{50}$ where Puqudeans lived (ša ina appāri Qatannu ašbu $) .{ }^{51}$ Furthermore, Nabû-šumu-lěšir, an official active in Babylonia, mentions in a letter to Ashurbanipal that he sent men of Birāte to the "marshy plain of Babylon" (ana sapanni apparu ša Bābili), where they were attacked by supporters of Šamaš-šumu-ukīn. ${ }^{52}$

Although we have no concrete information, at least one great lagoon seems to have existed in the Sealand. The term marratu, which denotes a body of salty water, refers usually-especially in the Neo-Assyrian royal inscriptions- to the Arabian Gulf. ${ }^{53}$ In Shalmaneser III's inscriptions, it is explicitly explained that the "Sea of Chaldea", namely the

45 RINAP 3/1, No. 1, 36-39 (Șahrīna is attested in line 38). According to Russell (2011, pp. 153-154) the reliefs from room LXX correspond to Sennacherib's first campaign, thus identifying indirectly Sahrīna with Șahrīna.

46 Cole (1994, pp. 90-96).

47 Cole (1994, p. 95 note 76) and Zadok (2006, pp. 394-397).

48 Layard (1853a, p. 500).

49 The sender of the letter is not preserved, but SAA 17, 142 was included among the letters sent by Nabûušallim (PNA 2/II, 903, s v. Nabû-ušallim 4) to Sargon, SAA 17, table on p. xxxvii.

50 SAA 17 , p. 199 , s. v.

51 SAA $17,142,9-11$.

52 SAA 18, 146, 6-16.

53 For the different names given to the Arabian Gulf see Yamada (2005, p. 55). 
Arabian Gulf, was also called marratu the "Bitter Sea". ${ }^{54}$ However, as has already been proposed, marratu was also used to denote a lagoon in the Sealand. ${ }^{55}$ It is striking that in Sargon's inscriptions, Bīt-Jakīn is referred to as the land "at the shore of the Bitter Sea (marratu)". ${ }^{56}$ Marratu can denote here the Arabian Gulf or a lagoon or both. Moreover, the easternmost border of Tiglath-pileser III's conquests is described as "from the Bitter Sea (marratu) of Bīt-Jakīn, as far as Mount Bikni ${ }^{57}$ in the East". ${ }^{58}$ Even if the expression "Bitter Sea of Bīt-Jakīn" can be understood as the Arabian Gulf, ${ }^{59}$ an interpretation as a main lagoon in the Sealand is also possible.

Evidence for a lagoon can be found in letters, where the expression bāb marrat "entrance of the Bitter Sea" (literally "mouth of the Bitter Sea") is used. ${ }^{60}$ From one of the letters sent by Bēl-ibni, military commander of the Sealand, to Ashurbanipal we learn that there existed a fortress (birtu) at the "entrance of the Bitter Sea". ${ }^{61}$ bāb marrat is always written KÁ-íd mar-rat without determinative, ${ }^{62}$ so that the existence of a city called $b \bar{a} b$ marrat is rather improbable. ${ }^{63}$ In a letter to Esarhaddon, Ubāru, the governor ( ̌̌akin țêmi) of Babylon, writes that the Chaldean chiefs "from Sippar to the entrance of the Bitter Sea" blessed the king as the one who resettled Babylon. ${ }^{64}$ In this case $b \bar{a} b$ marrat could refer to a lagoon ${ }^{65}$ or to the Arabian Gulf. ${ }^{66}$ However, two letters from Bēl-ibni to Ashurnasirpal point to an interpretation of marratu as lagoon. In one letter, he reports that troops sent by him were attacked 14 miles from the Sealand. ${ }^{67}$ He posted then 600 archers and 50 horsemen at the "entrance of the Bitter Sea" and sent them by rafts (hallimu) to the city of Mahminti. ${ }^{68}$ They looted there 1500 bulls from Elam and the people of Pillat. 500 of these animals were loaded on rafts and brought back to the Sealand, while the remaining thousand were stabbed and sunk in the "Bitter Sea" ('id marrat). ${ }^{69}$ As it is highly improbable that 500 bulls could be transported on rafts in the open sea or even near the seashore, the term marratu denotes in this context rather a lagoon in the Sealand. ${ }^{70}$ According to M.

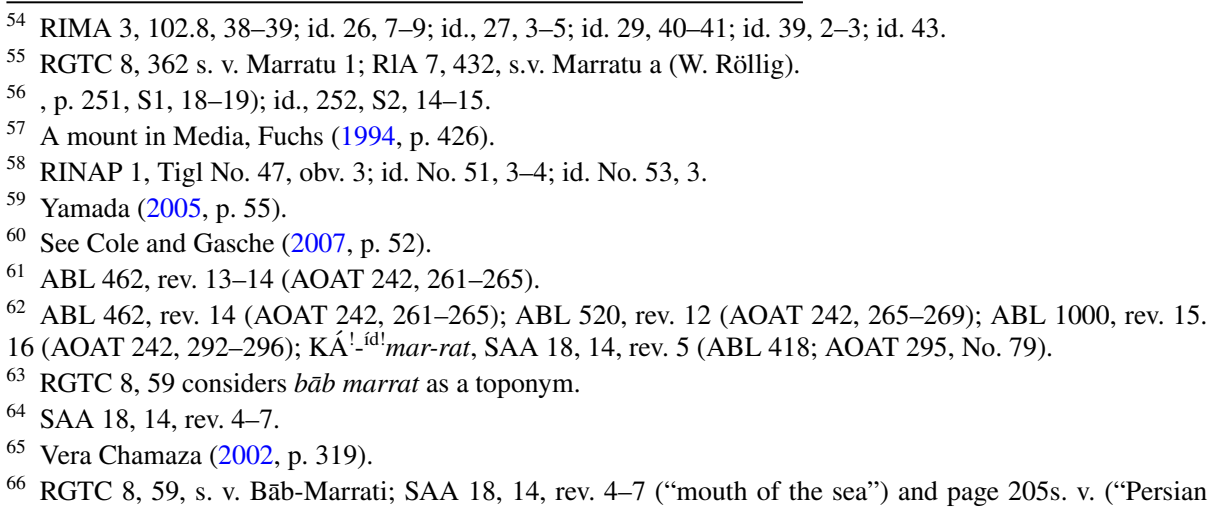
Gulf').

67 ABL 520, obv. 7 - rev. 10. The other letter is ABL 1000, where Bēl-ibni writes that 400 archers crossed the Bitter Sea with ships (ellepāte) to attack the confederates of Nabû-bēl-šumāte by surprise, rev. 6-12.

68 The place-name is otherwise not attested, RGTC 8, 217.

69 ABL 520, rev. 10-21. The stabbing of a great quantity of bulls is also mentioned in ABL 1000, rev. 9-10. In addition to the economic damage, to stab and sink hundreds of bulls in the lagoon may point to a measure against the Assyrian troops being pursued by the enemy, namely by putting obstacles between them.

70 The term bāb marrat is also attested twice in ABL 1000, rev. 16 and 17; in both cases distances "from the entrance of the Bitter Sea" are mentioned in fragmentary contexts (line 16 broken, line 1710 berru, i.e. 10 double-hours or 10 miles (approx. $100 \mathrm{~km}$ )). 
Dietrich, a big lagoon divided the Sealand in two parts: a northern part bordering on Elam and Gambūlu and a southern part identical with the marshland southwest of the former channel of the Euphrates. ${ }^{71}$

The lush vegetation of the marshland was not only a source of building materials, principally reeds - as tress would have been less abundant ${ }^{72}$ - but also provided a habitat for a variety of game, plants and other natural resources. Written and archaeological sources attest the exploitation of fish, mollusks, wild fowl and turtles from the Ur III period ${ }^{73}$ and earlier up to the time of Nebuchadnezzar II. ${ }^{74}$ After the submission of Mukīn-zēri of BītAmukkāni in the late years of Tiglath-pileser III's reign (731-729), the Chaldean king of the Sealand, Marduk-apla-iddina, brought tribute together with other local rulers to Sapija, the conquered rebel's capital. ${ }^{75}$ His wealthy tribute is described in detail, showing not only the variety of the natural resources of the marshland, but also attesting overseas trade: "I received as his payment natural, unrefined gold in great quantity, jewelry made of gold, a gold necklace, pearls (literally "precious stones, produce of the sea"), beams of ebony, ellūtu-wood, ašqulalu-plant(s), amīlānu-plant(s), multicolored garments, all types of aromatics, oxen, and sheep and goats". ${ }^{76}$

\section{The Sealand as hiding place}

This particular landscape with its marshes, swamps, canebrakes, lagoons and intertidal flats was much more than a rich natural environment, it was the perfect refuge to hide from pursuers and an excellent base to launch military operations against the Assyrian enemy and its confederates. At the time of Sargon's accession to the throne (722), Babylonia got lost and Marduk-apla-iddina ruled there for twelve years. In his twelfth regnal year (710), Sargon began the offensive against the usurper. Fearing the Assyrian army, part of the Aramaean population fled to "the Uqnû, a river which was difficult (to reach), and (among) the marshes (qanê api)". ${ }^{77}$ After the conquest of Dūr-Athara, a fortified city in Gambūlu, the Aramaean tribes of Ru'ūa, Hindaru, Jadburu, and Puqudu sought also refuge at the Uqnû River. ${ }^{78}$ Sargon blocked the Tupliaš River, built two forts, and starved them out, so that some of the refugees came out and submitted. ${ }^{79}$ During further military operations at the Uqnû, "the place of their concealment" (ašar tapzirtišunu), the environment was

\footnotetext{
71 Dietrich (1970, pp. 4-5). Dietrich's interpretation was followed by De Vaan (1995, 21 and 269), comment to line rev. 12, thus treating the historical events separately: purges in the northern Sealand (de Vaan 1995, pp. 61-62) and purges in the southern Sealand (de Vaan 1995, pp. 56-61).

72 In contrast to swamps, which are usually associated with trees (e.g., southern part of the US in Louisiana), marshland does not really have many (larger) trees.

73 Owen (1972) and Postgate (1994, p. 158).

74 VAB 4, 90, i, 19-20; id., 92, ii, 27-35 (especially 29-30); id., 94, iii, 13-14; id., 154, A iv, 38-39; id., 168, B vii, 19-21.

75 RINAP 1, Tigl No. 47, obv. 26-28.

76 RINAP 1, Tigl No. 47, obv. 27-28. In a letter to Ashurbanial, Bēl-ibni mentions among the property of Nabû-bēl-šumāte, the grandson of Marduk-apla-iddina, great quantities of bdellium and metals brought from Tilmun (Bahrain), ABL 791, obv. 4-13 (AOAT 242, 281-284).

77 Fuchs (1994, p. 140, Ann 272-274).

78 Fuchs (1994, p. 146, Ann 281-282).

79 Fuchs (1994, pp. 146-147, Ann 283-286). The Tubliaš River was probably an affluent of the Uqnû, s. Fuchs (2014-2016) (s. v. Tupliaš 1). Cole and Gasche (2007, pp. 34-35 (with Fig. 71 on page 32)) identify the Tubliaš River with the Dawairij.
} 
systematically destroyed, cutting any access to food, so that the resting refugees submitted to the Assyrian king. ${ }^{80}$ The Uqnû can most probably be identified with the lower course of the Kārūn, which at that time entered the Tigris within the marshland, some $80 \mathrm{~km}$ northwest of the place where it joins the Štt al-'Arab at present. ${ }^{81}$ During the following years (709-707), Sargon sieged and conquered Dūr-Jakīn, the main stronghold of Bīt-Jakīn. ${ }^{82}$ The annals report that Marduk-apla-iddina escaped, but his hiding place could not be found. ${ }^{83} \mathrm{He}$ probably fled into the marshes or to Elam. ${ }^{84}$

Only a few years later, in the accession year of Sennacherib, Marduk-apla-iddina regained once again the throne in Babylonia. He assembled a coalition of Chaldeans, Aramaeans, Babylonians and Elamites-which triggered Sennacherib's first campaign (late 704-early 702). ${ }^{85}$ When he marched with his army from Cutha to Kish, Marduk-aplaiddina fled, as already mentioned, to the marshes in Guzummānu: "He fled alone and escaped to the land Guzummānu, where he entered the swamp and marshes and (thereby) saved his life". ${ }^{86}$ Sennacherib's troops pursued him, but Marduk-apla-iddina could not be captured. We read in the report about this campaign: "For five days they sought him out, but his (hiding) place could not be found". ${ }^{87}$

Most probably, the marshes also turned out to be an ideal hiding place for Šūzubu, a Chaldean leader of Bīt-Dakkūri, who rebelled against Assyria and some years later would become king of Babylonia under the name of Mušēzib-Marduk (692-689). During his fourth campaign against Bīt-Jakīn (700), Sennacherib defeated Šūzubu, described as "a Chaldean who lives in the marshes", ${ }^{88}$ and about whom it is said "He fled alone like a lynx and his (hiding) place could not be found". 89 Then Sennacherib launched an offensive directly to Bīt-Jakinn, but Marduk-apla-iddina could flee again, this time to a swampy region in Elam. He took the statues of his gods and the bones of his ancestors, left his brothers at the shore of the sea (ahi tâmtim) and "flew away like a bird to the city of Nagite-raqqi, which is in the midst of the sea" ${ }^{90}$ Even if most texts describe the hiding place as an island ( ̌́a qabal tâmtim), in one case we read that "he crossed over to the city of Nagitu, which

\footnotetext{
80 Fuchs (1994, pp. 148-150, Ann 288-294).

81 Gasche 2007, 12-15 and 26-30; Frame (2014-2016, p. 355).

82 Fuchs (1994, pp. 159-169, Ann 329-373). For Marduk-apla-iddina's use of water as defensive measures. Bagg (2014, pp. 218-219) and Powell (1982).

83 Fuchs (1994, p. 166, Ann 360).

84 For Sargon's war against Marduk-apla-iddina see Brinkman (1964, pp. 18-22) and Fuchs (2011, pp. xiiiXxii).

85 For Sennacherib's campaigns in Babylonia see Brinkman (1964, pp. 22-27), Brinkman (1973), Levine (1982), and Mayer (1995).

${ }^{86}$ RINAP 3/1, No. 2, 6; id., No. 3, 6; see also RINAP 3/1, No. 1, 26 and RINAP 3/2, 213, 26.

87 RINAP 3/1, No. 1, 34 and RINAP 3/2, 213, 34.

${ }^{88}$ RINAP 3/1, No. 15, iv, 19'; id., No. 16, iv, 42-43; id., No. 17, iii, 86-87; id., No. 18, iii, 5'; id., No. 22, iii, 53; id., No. 23, iii, 46; RINAP 3/2, No. 46, 33.

${ }^{89}$ RINAP 3/1, No. 15, iv, 23'; id., No. 16, iv, 47-48; id., No. 17, iii, 90-91; id., No. 18, iii, 9'-10'; id., No. 22, iii, 56-57; id., No. 23, iii, 48-49; also RINAP 3/2, 46, 34. Against PNA 3/II, 1297, s. v. Šūzubu (Mušēzib-Marduk) 3, it is not explicitly said that Šūzubu fled at that time to Elam.

90 RINAP 3/1, No. 15, iv, 26'-34'; id., No. 16, iv, 51-61 (omits the divine images); id., No. 17, iii, 94 - iv, 9; id., No. 18, iii, 12'-24'; id., No. 21, ii', 1'-8' (omits the divine images); id., No. 22, iii, 59-69; id., No. 23, iii, 51-60. Shorter variants of the same episode are RINAP 3/1, No. 26, i, 4'-5'; id., No. 34, 8-10 (adds the bones of the ancestors); RINAP 3/2, No. 46, 34-36; id., No. 141, 4'-5'; id., No. 231, 9-11 (adds the bones of the ancestors).
} 
is on the other side of the Bitter Sea ( $\check{s} a$ ebertān ${ }^{\text {id }}$ marrat). In that place he disappeared". ${ }^{91}$ Nagītu or Nagite-raqqi was probably situated on an island in the marshes, either on the eastern side of the lagoon in the Sealand (the ancient equivalent of the Haur al-Hammār) ${ }^{92}$ or on the Iranian side of the Arabian Gulf, as might be concluded from the description of Sennacherib's sixth campaign (see below).

The Sealand and its marshes were also chosen by the Elamite king Tammaritu, who plotted at the side of Šamaš-šuma-ukīn against Ashurbanipal. He was defeated by the Assyrian king and, according to a caption in a collection of epigraphs, he "fled and took the road to the Sealand". 93 The following epigraph on the tablet seems to refer to a scene in the marshes, where it was difficult to hide by ship: "the ship of Tammaritu, king of Elam, ..., which was mired in the mud flats, swamps, and morass". 94

\section{The Sealand as military landscape}

The Mesopotamian marshes were not only a place to hide away, but also an ideal base for launching military operations against the Assyrian invaders. During Sennacherib's eighth campaign (691-late 689), Mušēzib-Marduk, then king of Babylon, rebelled one more time and gathered Aramaean fugitives and criminals around him. Sennacherib's inscriptions tell us that "they went down to the marshes and incited rebellion". ${ }^{95}$ The revolt could be subdued, but Mušēzib-Marduk fled again, this time to Elam. ${ }^{96}$

The marshland in southern Babylonia was an extremely difficult terrain for the Assyrian army, not only because the enemy knew the landscape very well and was hard to be found. Moving in the marshes was no simple undertaking anyway, let alone displacing an army through a territory with marshes and lagoons, where firm soil was the exception, especially taking into account that Assyria was no maritime power. In 694, Sennacherib decided to punish the people of Bīt-Jakīn, who took refuge in Elamite territory. The first targets of his sixth campaign were the cities Nagītu and Nagītu-di'bina, which in some inscriptions are described as "cities of the king of Elam whose dwellings are situated on the other shore of the Bitter Sea ( ̌sa ina ebertān ${ }^{\text {id }}$ marrati) $) .{ }^{97}$ In this case, there is no doubt that marratu refers to the Arabian Gulf, as in other texts describing the same event, we read that the fugitives of Bīt-Jakīn "crossed the Great Sea of the Rising Sun (tâmtum rabītum ša șìt $\check{S}$ amši ) and set up their residences in the city of Nagītu of the land Elam", 98 being tâmtum rabītum ša șit $\breve{S} a m s ̌ i$ one of the names of the Arabian Gulf. ${ }^{99}$

\footnotetext{
91 RINAP 3/1, No. 34, 8-10.

92 Brinkman (1984, 60 with note 286) and Frame (1998-2001).

93 BIWA 315, 68, rev. 31 (=Weidner 1932-1933, 198, No. 68, 31).

94 BIWA 315, 69, rev. 33-34 (=Weidner 1932-1933, 198, No. 69, 33-34); translation after CAD R, 432, s. v. rušumtu 1.

95 RINAP 3/1, No. 22, v, 17-24; id., No. 23, v, 9-16.

96 RINAP 3/1, No. 22, v, 24-30; id., No. 23, v, 16-22.

97 RINAP 3/1, No. 46, 48-55. Other texts have "I conquered the cities Nagiatu, Nagiatu-di'bina, Hilmu, Pillatu, and Hupapanu, districts on the other shore of the Bitter Sea (̌̌a ebertān id marrati)", RINAP 3/2, No. 44, 28-30; also id., No. 143, i, 6'-7' and id., No. 230, 17-18.

98 RIMAP 3/2, No. 22, iv, 32-36; id., No. 23, iv, 26-30. Other texts have "the cities Nagiatu and Nagiatudi'bina, the lands Hilmu, Pillatu, and Hupapanu, districts on the other shore of the sea (̌sa ebertān tâmtim)", RINAP 3/1, No. 34, 20-21.

99 For the names of the Arabian Gulf see Yamada (2005, pp. 52-55).
} 
On this occasion, seafaring ships were needed and Sennacherib let them build and sail by skilled Phoenician shipbuilders and mariners. ${ }^{100}$ The ships were built in Nineveh and first sailed down the Tigris up to Opis. From there, they were dragged by land to Sippar and guided into the Arahtu canal, from where they were sailed further downstream to the canal of Bīt-Dakkūri. Finally, they were sailed down the Euphrates to Bāb-salimeti, not far from the shore of the Arabian Gulf. A very complicated procedure indeed, which was closely followed by the king ... from the land. From Sennacherib's report we learn about the effect of the tide in this southernmost part of the Sealand: "The high tide of the sea rose mightily, and (then) entered my tent and completely surrounded my entire camp. For five days and nights, on the account of the strong water, all of my soldiers had to sit curled up as though they were in cages". ${ }^{101}$ Finally the ships "reached the marshy area at the mouth of the river, where the Euphrates debouches its water into the roiling sea". ${ }^{102}$ Sennacherib remained at the shore, where he made sacrifices and let his ships sail across the Gulf. ${ }^{103}$ The campaign was a success and the ships returned to Bāb-salimeti with rich booty and many captives. ${ }^{104}$ It is interesting to remark that the disembarkation on the opposite shore of the Gulf, probably also a marshy landscape, was difficult. The shore of the roiling sea is described as "unsuitable and very difficult (for ships) to dock, horses to climb, and men to set foot on". 105

According to the correspondence of Bēl-ibni, the military commander of the Sealand, who was loyal to Ashurbanipal, we learn that boats or rafts were used for operations in the marshes and the lagoon. Rafts (hallimu) were used, for instance to transport Bēl-ibni's troops from the "entrance of the Bitter Sea" to the city of Mahmīti and to bring them back with 500 bulls. ${ }^{106}$ Another letter reports that Nabû-bēl-šumāti, the grandson of Marduk-apla-iddina, attacked Bēl-ibni, sending troops with rafts (hallimu). Bēl-ibni's counteroffensive was undertaken by 400 archers sent to enemy territory with ships (eleppāte) which crossed the lagoon (or the Gulf?) to Elam. ${ }^{107}$ In another case, Bēl ibni reports that Nabû-bēl-šumāte's attacks were done with few troops. He asks Ashurbanipal for $70 \operatorname{logs}$ to be floated up to Opis and from there to be brought in direction of the sea to Kăr-Nanâ; he also asks for 20 Sidonians to build the ships (eleppāte). ${ }^{108}$ These vessels were not mere boats or rafts, but probably seagoing ships; if they were used for operations across the Gulf or just in the lagoon remains an open question. ${ }^{109}$

\footnotetext{
100 The longest and most detailed report of this campaign is an inscription on two bull colossi from a door in court H of Sennacherib's Southwest Palace in Nineveh, RINAP 3/2, No. 46, 48-108. For the identification of the ancient watercourses involved in this amphibian campaign see Cole and Gasche (2007, pp. 47-49).

101 RINAP 3/2, No. 46, 74-76.

102 RINAP $3 / 2$, No. 46, 76-78.

103 RINAP $3 / 2$, No. 46, 78-80.

104 RINAP 3/2, No. 46, 81-102.

105 RINAP $3 / 2$, No. 46, 81-82.

106 ABL 520, rev. 9-21 (AOAT 242, 265-269).

107 ABL 1000, obv. 11-rev. 7 (AOAT 242, 292-296).

108 ABL 795 + CT 54, 555, rev. 7-12 (AOAT 242, 289-292).

109 Also the fragmentary letter ABL 1342 (AOAT 242, 318-322) seems to be about troops to be sent by ship, s. De Vaan (1995, p. 57). Boats in the marshes are mentioned in a badly broken letter, probably addressed to Sennacherib, SAA 17, 85, 5' (ina libbi eleppāte ana libbi appāri). A further incident in the marshes is attested in Sargon's correspondence. A badly broken letter mentions that Assyrians attacked people hidden in the reed thicket, SAA 15,38 .
} 
Further evidence for the Sealand and its marshy landscape comes from the iconographical material, namely the palace reliefs. The scenes depicting military actions in the marshes confirm the information of the written sources and give a vivid image of the landscape and the dramatic events that happened there. A slab from Room LXX of Sennacherib's Southwest Palace shows a battle in a marsh ${ }^{110}$ (Fig. 3). The historical context is known as the adjoining slabs ${ }^{111}$ show a grove of palm-trees, where Sennacherib standing in his chariot receives the prisoners and the heads of the slain. An already mentioned epigraph labels the scene as "the booty from the marshes of Sahrīna". ${ }^{112}$ As has been said, this room was most probably decorated with scenes of Sennacherib's first campaign. We see the two main features of the Sealand: the canebrakes and the water, where fishes and eels can be perceived. The Assyrian soldiers are depicted on boats with slightly upturned prow, made of bundles of reeds tied together with bands. ${ }^{113}$ Boats navigating toward the left show warriors still shooting arrows. Boats navigating toward the right show soldiers bringing captives to the shore. One of these boats is towed by a man swimming over an inflated skin. The beheaded corpses of defeated enemies floating in the water complete the scene.

Two other slabs from court LXIV show a similar scene, but cannot definitely be linked with one of Sennacherib's Babylonian campaigns ${ }^{114}$ (Fig. 4). The battle scene is bordered by canebrakes, which are traversed by small watercourses. In this case, six flat-bottomed reed boats are depicted, three of them are manned by Assyrian soldiers shooting arrows on three other boats, where native archers and women are shown. The construction type of the boats is the same as on the slabs from room LXX, but the Assyrian ones are longer ${ }^{115}$ and punted from the stern. At the top, a row of prisoners is conducted to the right by Assyrian soldiers. At the bottom of slab 7, another row of male and female captives is depicted advancing towards the right. Also of interest are the Assyrian horsemen, who scour the canebrakes for hidden enemies. The picture shows clearly that the marshland consisted of canebrakes traversed by channels and also of larger bodies of water, probably not too deep, but at least in some cases deep enough to allow the use of watercraft.

An even more lively and detailed picture of a battle in the marshes of southern Babylonia dates from the reign of Ashurbanipal and comes from room XXVIII of the Southwest Palace, one of the rooms which was redecorated after the reign of Sennacherib ${ }^{116}$ (Fig. 5). The scene shows again Assyrian soldiers fighting or transporting prisoners to the shore on reed boats. ${ }^{117}$ The boats are of the same type as in Sennacherib's reliefs and their light

\footnotetext{
110 Barnett (1998b, pl. 463, No. 643 (slab 1); Layard 1853b, pl. 28) (Or. Dr. IV, 42); see also De Graeve (1981, pp. 48-49, No. 51).

111 The directly adjoining slab 2 was not drawn and is not preserved, but it showed most probably the continuation of the file of deportees brought to the shore.

112 Barnett (1998b, pl. 462, No. 645 (slab 3) and 646 (slab 4); id., pl. 464, No.. 645a; id., pl. 466, No. 646a).

113 For reed boats see De Graeve (1981, pp. 90-93).

114 Barnett (1998b, pl. 450, No. 611 (slab 5) and 613 (slab 7); id., pl. 454, No. 611a and pl. 455, No. 613a); Layard (1853b, pl. 27) (Or. Dr. IV, 33); see also De Graeve (1981, p. 49, No. 52).

115 Most probably the depiction of the Assyrian boats as longer rather followed a convention of representation than that it reflected a larger size in reality.

116 According to Russell (2011, p. 151) the reliefs in room XXVII and court XIX as well as some slabs in room XXII date from the reign of Ashurbanipal.

117 Barnett (1998b, pl. 233, No. 340) (slabs 2-3, BM WA 124774a+b) and 341 (slab 4, BM WA 124744c +d); id., pl. 236, No. 340a (slab 3, drawing); id., pl. 237, No. 340b (slab 3, photo) and details on pl. 234-235 and 238-239 (all No. 340); Layard (1853b, pl. 25); see also De Graeve (1981, pp. 53-54, No. $60)$.
} 


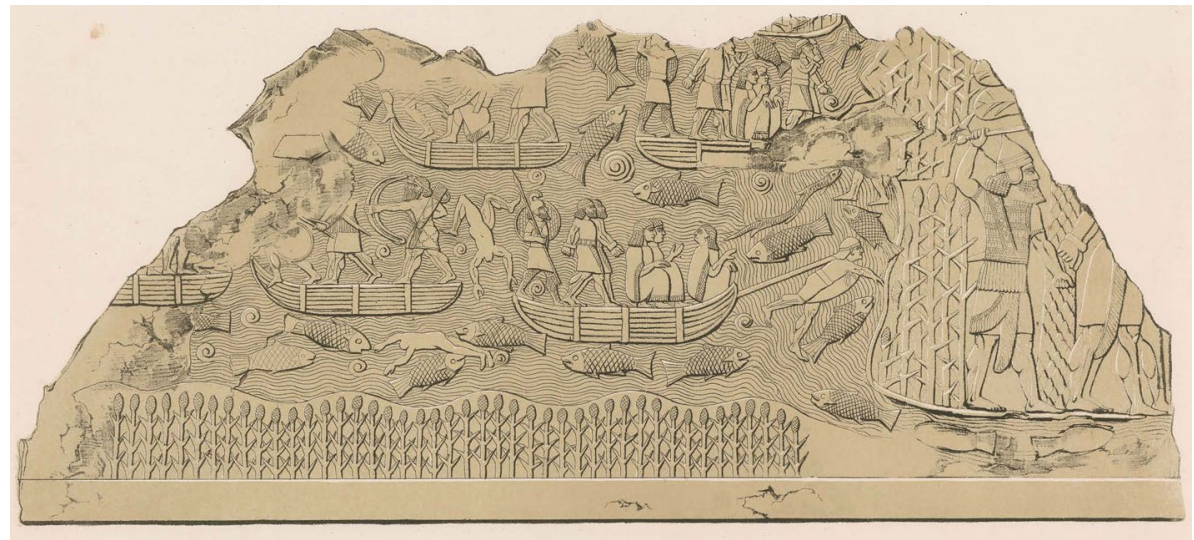

Fig. 3 Battle in the marshes; reign of Sennacherib (Nineveh, Southwest Palace, room LXX, slab 1). Source Layard (1853b, pl. 28)

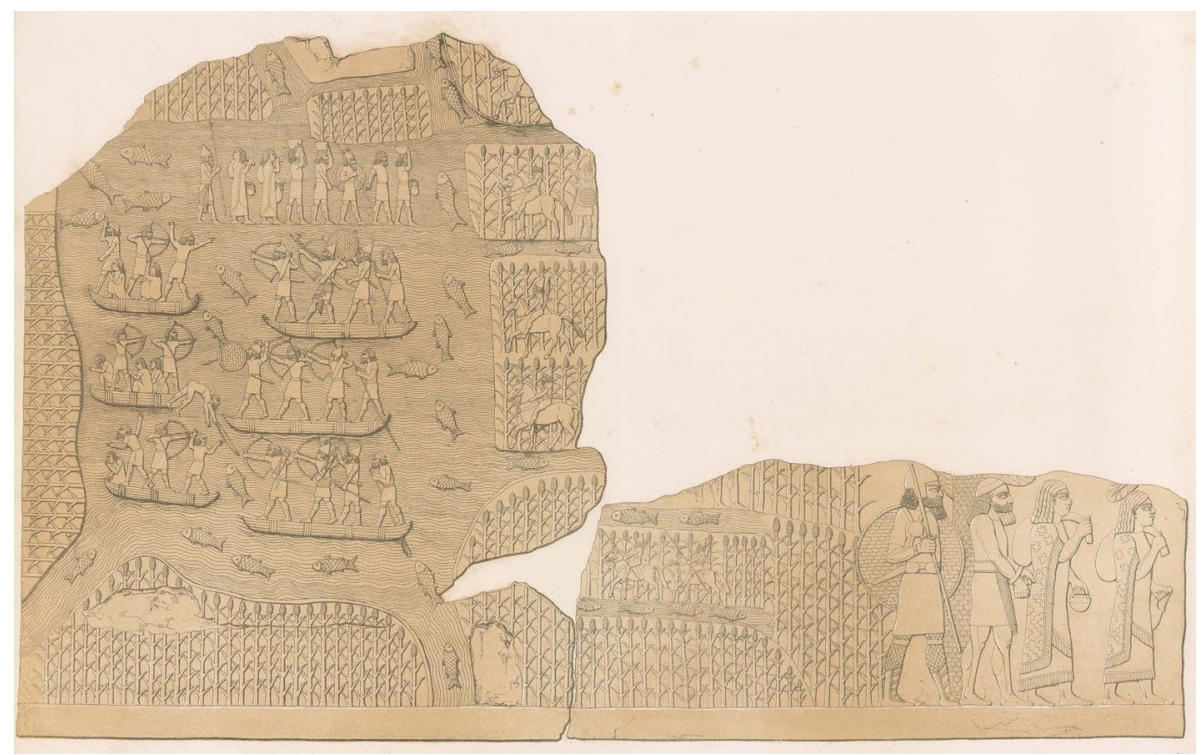

Fig. 4 Battle in the marshes; reign of Sennacherib (Nineveh, Southwest Palace, court LXIV, slab 5-7). Source Layard (1853b, pl. 27)

structure is revealed by a detail on the right showing the disembarkation of prisoners: the boat could be held by one soldier. Most of the vessels of the marsh dwellers are hidden in the canebrakes, pressing the reeds under their weight. Some vessels are flat rafts made also of reeds tied together with bands. The hidden men and women are sitting on the rafts, hoping not to be discovered by the Assyrians. Some of them are shooting arrows, taking advantage of the surprise effect, which at the same time revealed their hiding place. As in 


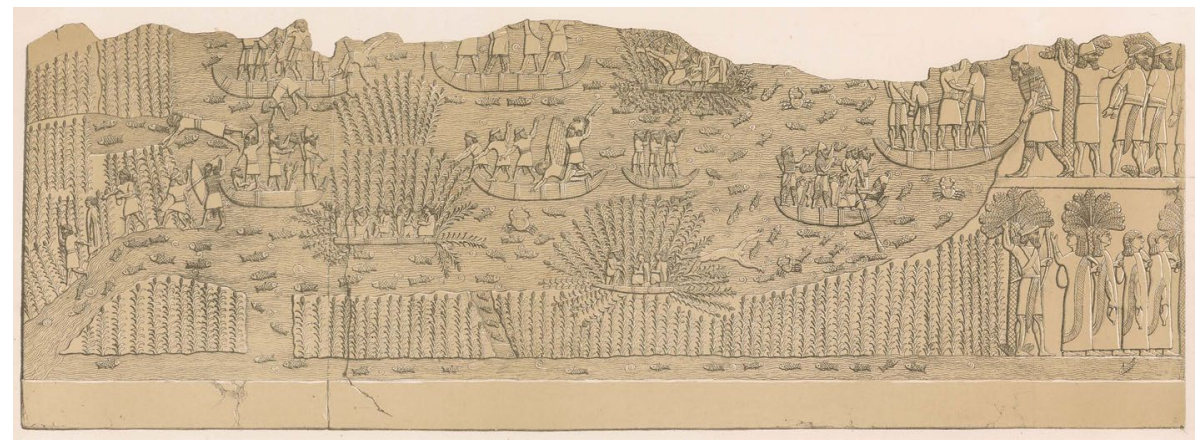

Fig. 5 Battle in the marshes; reign of Ashurbanipal (Nineveh, Southwest Palace, room XXVIII, slabs 2-4). Source Layard (1853b, pl. 25)

the other depictions, prisoners are conducted to the palm groves by Assyrian soldiers. ${ }^{118}$ Further reliefs from room F in Ashurbanipal's North Palace in Nineveh show Elamite people taking refuge in the marshes after the conquest of the city of Hamānu ${ }^{119}$ during Ashurbanipal's second campaign against Ummanaldasi (647/6). ${ }^{120}$

\section{The Sealand as a contested space}

The Sealand, a region of marshes, swamps, lagoons, and intertidal flats was the setting of fighting between the Assyrian army and marsh dwellers who rebelled against the imperial power. It was an ideal hiding place for fugitives, who, as well as those living there, knew the terrain very well. For the mighty Assyrian army it was a difficult terrain, so that the struggles extended for a long time. The Sealand and its most famous rebel Marduk-aplaiddina could resist for many years, in great part thanks to this particular landscape. Both environment and rebels were thorns in the flesh of the most powerful Assyrian kings from Sargon to Ashurbanipal. Given the difficulties that the marshlands created for the Assyrian army to go through, let alone control, the strategic implications of the marshlands — at least

\footnotetext{
118 Two further relief fragments showing military operations in the marshes may also belong to room XXVIII (Barnett 1998a, p. 90): Barnett (1998b, pl. 264, No. 352 (IM 26230) and No. 353 (Museo Barraco 50)). The fragment in the Iraq Museum (IM 26230) shows the embarkation of prisoners after the conquest of a fortified city, probably in Elam, the name of which is fragmentarily preserved as caption ( ${ }^{\text {uru }}$ qi-BI/ GAB), s. also De Graeve (1981, p. 54, No. 61) and Falkner (1952-1953, pp. 249-251 with Fig. 40).

119 Barnett (1976, pl. XVI), upper register (BM 124929-124930); id., pl. XVII, upper register (BM 124931-124932); id., pl. XVIII, upper register (BM 124933-124934); id., pl. XX, upper register (Or. Dr. IV, 3; original lost); id., pl. XX, upper register (Or. Dr. IV, 5; only fragments from original preserved); for the last scene see also De Graeve (1981, pp. 55-56, No. 64). A further fragment in the Durham Oriental Museum can also be included among those from room F: Barnett (1976, pl. XXI), fragment d and Falkner (1952-1953, 247 Fig. 39) (Durham 2) and 248. Another scene depicting most probably a battle in the marshes comes from court $\mathrm{J}$ in Ashurbanipal's North Palace. The original was badly damaged and the scene is only preserved as a drawing, Barnett 1976, pl. XXVIII, Or. Dr. VII, 15 (slab 3), De Graeve (1981, pp. 56-57, No. 66).

${ }^{120}$ BIWA 49, A v, 67-68=F, iv, 21 mentions explicitly the conquest of Hamānu and Rāši. However, Hamānu is already mentioned among other cities conquered during his first campaign against Ummanaldasi (648/7), BIWA 48-49, A v, 43-58=F, iv, 1-12 (Hamānu occurs in A v, 46=F, iv,3).
} 
in terms of military and political control, but also possibly in terms of resources-for the Assyrian state were huge.

More work on this theme is needed, but perhaps we get a glimpse of this importance of the Sealand for the Assyrian state, when we consider that the marshland in southern Babylonia fascinated at least one of the Sargonides to such an extent that he reproduced this exotic landscape in the homeland. Around $699,{ }^{121}$ only a few months after his second Babylonian campaign (700), Sennacherib created an artificial swamp to regulate the surplus water of his first canal system, which was probably located near Nineveh" ${ }^{122}$ : "I created a marsh (agammu) to moderate the flow of water for those gardens and planted a canebrake (șuŝu) in it. I let loose in it herons, wild boars, and roe deer.... The marshes (appāru) thrived greatly. Birds of the heavens, herons, made nests and wild boars and roe deer gave birth in abundance". ${ }^{123}$

This nature reserve was depicted on wall reliefs from court VI in Sennacherib's Southwest Palace $^{124}$ and also on those fallen from room S in Ashurbanipal's North Palace. ${ }^{125}$ Sennacherib also says that he cut off reed from his marsh and used it as building material for his palaces. ${ }^{126}$ Sennacherib's description of the artificial marsh and the depicted scenes convey a peaceful atmosphere which contrasts with a furious Ashurbanipal when he wrote to Bēl-ibni: "Go to the Sealand ... and kill them all!". ${ }^{127}$

Acknowledgements Open Access funding provided by Projekt DEAL.

Open Access This article is licensed under a Creative Commons Attribution 4.0 International License, which permits use, sharing, adaptation, distribution and reproduction in any medium or format, as long as you give appropriate credit to the original author(s) and the source, provide a link to the Creative Commons licence, and indicate if changes were made. The images or other third party material in this article are included in the article's Creative Commons licence, unless indicated otherwise in a credit line to the material. If material is not included in the article's Creative Commons licence and your intended use is not permitted by statutory regulation or exceeds the permitted use, you will need to obtain permission directly from the copyright holder. To view a copy of this licence, visit http://creativecommons.org/licenses/by/4.0/.

\section{References}

Al-Mudaffar Fawzi N, Goodwin KP, Mahdi BA, Stevens ML (2016) Effects of Mesopotamian Marsh (Iraq) desiccation on the cultural knowledge and livelihood of Marsh Arab women. Ecosyst Health Sustain 2(3):e01207

\footnotetext{
121 First attested in inscriptions from 699: RINAP 3/1, No. 8, 5'-6' and RINAP 3/2, No. 138, rev. ii', 35-36.

122 Bagg (2000, pp. 182-187).

123 RINAP 3/2, No. 46, 157-158a and 159b-160 and the following parallel passages (see also note 120): RINAP 3/1, No. 15, viii, 1"-3"; id., 16, viii, 29-33 and 40-44; id., 17, viii, 46-49 and 56-59; 18, viii, 7"-10" and 14"-17".

124 Barnett 1998b, pl. 79, No. 148 (slab 61) with pl. 108 and 109, No. 147 and No. 184 (Bagg 2000 , pl. 44-46); Barnett 1998b, pl. 106, No. 147 (slab 58; Bagg 2000, pl. 47).

125 Barnett 1976, pl. LXIII, slab A (Or. Dr. vi, 41; Bagg 2000, pl. 49); id., slab D (Or. Dr. v, 43); id., slab E (Or. Dr. v, 45; Bagg 2000, pl. 50). A further scene comes also from room S: Barnett 1976, pl. XLIV, slab 21 (Or. Dr. V, 19; Bagg 2000, pl. 50).

126 RINAP 3/1, No. 8, 7'; id., 15, viii, 4"-7”; id., 16, viii, 45-51; id., 17, viii, 60-63; id., 18, viii, 17'b-20"a; RINAP 3/2, No. 46, 160b-161.

127 ABL 1342, rev. 7-8 (AOAT 242, 318-322).
} 
Aqrawi AAM (2001) Stratigraphic signatures of climatic change during the Holocene evolution of the Tigris-Euphrates delta, lower Mesopotamia. Glob Planetary Change 28:267-283

Arnold BT (1985) Babylonian letters from the Kuyunjik collection: seventh century Uruk in the light of the epistolary evidence. PhD Dissertation, Hebrew Union College (Ohio), Ann-Arbor

Bagg AM (2000) Assyrische Wasserbauten. BaF 24. Mainz

Bagg AM (2014) Water as weapon and military target in ancient Mesopotamian warfare. In: C Ohlig, T Tsuk (eds) Cura Aquarum in Israel II. Schriften der Deutschen-Wasserhistorischen Gesellschaft 21. Siegburg, pp 215-226

Bagg AM (2019) The Neo-Assyrian Empire and its chronological and geographical frameworks. In: Lanfranchi GB, Mattila R and Rollinger R (eds) Writing Neo-Assyrian History: Sources, Problems, and Approaches. The Neo-Assyrian Text Corpus Project, Helsinki (State Archives of Assyria Studies 29), pp $27-44$

Barnett RD (1976) Sculptures from the North Palace of Ashurbanipal at Nineveh. Oxford University Press, Oxford

Barnett RD (1998a) E. Bleibtreu and G. Turner, Sculptures from the Southwest Palace of Sennacherib at Nineveh, vol 1. British Museum Press, London

Barnett RD (1998b) E. Bleibtreu and G. Turner, Sculptures from the Southwest Palace of Sennacherib at Nineveh, vol 2. British Museum Press, London

Brinkman JA (1964) Merodach-Baladan II. In: Biggs RD, Brinkman JA (eds) Studies presented to A. Leo Oppenheim. University of Chicago Press, Chicago, pp 6-53

Brinkman JA (1973) Sennacherib's Babylonian problem: an interpretation. J Cuneiform Stud 25:89-95

Brinkman JA (1984) Prelude to empire. Babylonian Fund, University Museum, Philadelphia

Brinkman JA (1993-1997) Meerland (Sealand). RlA 8:6-10

Brinkman JA, Seidl U (1987-1990) Marduk-apla-iddina. RlA 7:374-375

Cole SW (1994) Marsh formation in the Borsippa region and the course of the Lower Euphrates. J Near East Stud 53:81-109

Cole SW, Gasche H (2007) In: Gasche H (ed) Documentary and other archaeological and environmental evidence bearing on the identification and location of the rivers of Lower Khuzestan and the position of the head of the Persian Gulf ca. 1200 BC-200 AD, pp 5-54

de Graeve M-C (1981) The ships of the Ancient Near East (c. 2000-500 B.C.). OLAS 7. KUL Departement oriëntalistiek, Leuven

de Morgan J (1900) Étude géographique sur la Susiane. MDP 1:1-32

de Vaan JMTC (1995) "Ich bin eine Schwertklinge des Königs". Die Sprache des Bēl-ibni (AOAT 242). Neukirchen-Vluyn

Dietrich M (1970) Die Aramäer Südbabyloniens in der Sargonidenzeit (AOAT 7). Neukirchen-Vluyn

Fales FM (2011) Moving around Babylon: on the Aramaean and Chaldean presence in South Mesopotamia. In: Cancik-Kirschbaum E, van Ess M, Marzahn J (eds) Babylon. Wissenskultur in Orient und Okzident, Berlin, pp 91-112

Falkner M (1952-1953) Die Reliefs der assyrischen Könige. Zweite Reihe. 4. Zwei Reliefs in Durham. Archiv für Orientforschung 16:246-251

Frame G (1992) Babylonia 689-627 B. C. A Political History. Nederlands Instituut voor het Nabije Oosten, Leiden

Frame G (1998-2001) Nagītu. RlA 9:80

Frame G (2014-2016) Uqnû. RlA 14:354-355

Fuchs AS (1994) Die Inschriften Sargons II. aus Khorsabad. Cuvillier, Göttingen

Fuchs A (2011) Introduction. In: Fuchs A, Parpola S (eds) The correspondence of Sargon II, Part II: letters from Babylonia and the Eastern Provinces (SAA 15). Helsinki University Press, Helsinki, pp xiii-liv

Fuchs A (2014-2016) Tupliaš. In: RlA 14, pp 190-191

Gasche H (ed) (2004) The Persian Gulf shorelines and the Karkheh, Karun, and Jarrahi Rivers: a geoarchaeological approach. A joint Belgo-Iranian project. First progress report. Akkadica 125:141-215

Gasche H (ed) (2005) The Persian Gulf shorelines and the Karkheh, Karun, and Jarrahi Rivers: A geoarchaeological approach. A joint Belgo-Iranian project. First progress report part 2. Akkadica 126: $1-43$

Gasche H (ed) (2007) The Persian Gulf shorelines and the Karkheh, Karun, and Jarrahi Rivers: a geo-archaeological approach. A joint Belgo-Iranian project. First progress report part 3. Akkadica 128:1-72

Heimpel W (1987) Das Untere Meer. Z Assyriol 77:22-91

Heyvaert VMA, Baeteman C (2007) Holocene sedimentary evolution and palaeocoastlines of the lower Khuzestan plain (SW-Iran). Mar Geol 242:83-108

Hritz CA (2005) Landscape and settlement in Southern Mesopotamia. A geo-archaeological analysis. PhD Dissertation, Chicago University Press, Ann Arbor 
Hritz CA, Pournelle J, Smith J (2012) Revisiting the Sealands: Report of preliminary ground reconnaissance in the Hammar district, Dhi Qar and Basra governorates, Iraq. Iraq 74:37-49

Jema WS (2015) Social-ecological assessment framework for the restoration of the Iraqi Mesopotamian Marshlands. PhD dissertation, Ann Arbor

Layard AH (1853a) Discoveries Among the Ruins of Nineveh and Babylon. London

Layard AH (1853b) A Second Series of the Monuments of Nineveh. London

Levine L (1982) Sennacherib's Southern Front: 704-689 B.C. J Cuneiform Stud 34:28-58

Machinist P (1984-1985) The Assyrians and their Babylonian problem: some reflections. Wissenschaftskolleg zu Berlin, Berlin, pp 353-364

Mayer W (1995) Sanherib und Babylonien: Der Staatsmann und Feldherr im Spiegel seiner Babylonienpolitik. In: M Dietrich, O Loretz (eds) Vom Alten Orient zum Alten Testament: Festschrift für Wolfram Freiherrn von Soden zum 85. Geburtstag am 19. Juni 1993. AOAT 240, pp 305-332

Nicholson E, Clark P (2002) The Iraqi Marshlands: a human and environmental study. Politico Publishing, London

Owen DI (1972) On birds, eggs, and turtles. Z Assyriol 71:29-47

Parpola S, Porter M (2001) The Helsinki Atlas of the Near East in the Neo-Assyrian Period. Casco Bay Assyriological Institute, Helsinki

Postgate JN (1994) Early Mesopotamia (2nd revised edn). Roudedge, London

Pournelle JR, Algaze J (2004) Travels in Edin: deltaic resilience and early urbanism in Greater Mesopotamia. In: Mcmahon A, Crawford H (eds) Preludes to urbanism: The Late Chalcolithic of Mesopotamia. Cambridge University Press, Cambridge, pp 5-37

Powell M (1982) Merodach-Baladan at Dur-Jakin: a note on the defense of Babylonian cities. J Cuneiform Stud 34:59-61

Russell JM (2011) Sennacherib's palace without rival at Nineveh. University of Chicago Press, Chicago

Sanlaville P (1989) Considérations sur l'évolution de la basse Mésopotamie au cours des derniers millénaires. Paléorient 15(2):5-27

Sauter M (2016) “Garden of Eden”-preserved for posterity. BAR 42(2):16-18

Streck MP (2014) Babylonia. In: Niehr H (ed) The Aramaeans in Ancient Syria. Brill, Leiden, pp 297-318

United Nations Environment Programme (2001) The Mesopotamian marshlands: demise of an ecosystem, early warning and assessment. Early warning and assessment. Division of Early Warning and Assessment, United Nations Environment Programme, Nairobi

Unger E (1931) Babylon. Die heilige Stadt nach der Beschreibung der Babylonier, Berlin

Vera Chamaza GW (2002) Die Omnipotenz Aššurs: Entwicklungen in der Aššur-Theologie unter den Sargoniden Sargon II., Sanherib und Asarhaddon. AOAT 295. Münster

Waetzold H (1981) Zu den Strandverschiebungen am Persischen Golf und den Bezeichnungen der Hors. In: Schäfer J, W Simon W (eds) Strandverschiebungen in ihrer Bedeutung für Geowissenschaften und Archäologie. Ruperto Carola, Sonderheft, Heidelberg, pp 159-185

Weidner E (1932-1933) Assyrische Beschreibungen der Kriegs-Reliefs Aššurbânipals. Archiv für Orientforschung 8:175-203

Wilkinson TJ (2012) Introduction to geography, climate, topography, and hydrology. In: Potts DT (ed) A companion to the archaeology of the ancient near east. Wiley, Oxford, pp 3-26

Wilkinson TJ (2013) Hydraulic landscapes and irrigation systems of Sumer. In: Crawford H (ed) The Sumerian World. Routledge, London, pp 33-54

Yamada K (2005) "From the upper sea to the lower sea". The development of the names of the seas in the Assyrian royal inscriptions. Orient 40:31-55

Zadok R (2006) The geography of the Borsippa region. In: Amit Y et al (eds) Essays on Ancient Israel in its near Eastern context. A tribute to Nadav Na'aman. Eisenbrauns, Winona Lake, pp 389-454

Zadok R (2013) The onomastics of the Chaldean, Aramean, and Arabian tribes in Babylonia during the first millennium. In: Berlejung A, Streck MP (eds) Arameans, Chaldeans, and Arabs in Babylonia and Palestine in the First Millennium B. C. Harrassowitz Verlag, Wiesbaden, pp 261-336

Publisher's Note Springer Nature remains neutral with regard to jurisdictional claims in published maps and institutional affiliations. 